\title{
Meeting in Finland
}

Vapaan sivistystyön yhteisjärjestö toimii alansa sivistys- ja keskusjärjestöjen palveluelimenä. Jäsenistön sille osoittamien kotimaisten tehtävien lisäksi se pitää yllä huomattavan osan ulkomaisista yhteyksistä. Järjestön kansainvälisen toiminnan päätapahtuma on Meeting in Finland -seminaari.

\section{Meeting}

Kuluvana vuonna seminaari järjestettiin Turun kristillisessä opistossa touko-kesäkuun vaihteessa. Teemana oli Aikuiskasvatuksen tämän hetken ajankohtaiskysymykset idässä ja lännessä, etelässä ja pohjoisessa. Aihe saattaa tuntua suomalaisesta lavealta, mutta sitä arvioitaessa on otettava huomioon osanottajien hyvin erilaiset kulttuuri- ja kokemustaustat.

Meetingistä on vuosien myötä kehittynyt hyvin suosittu. Tämä käy ilmi mm. siitä, että siihen pääsyä anoi yli 150 ulkomaista aikuiskasvattajaa. Heistä 74 voitiin kutsua seminaariin. Osanottajaryhmän koostumus jakautui kokonaisuutena seuraavasti:

- Aasian maista 6

- Afrikan maista 12

- Itä-Euroopasta 17,

- Länsi-Euroopasta 27

- Latinalaisesta Amerikasta 4,

- Kanadasta ja Yhdysvalloista 8 sekä

- Suomesta 17.

Mukana olijat edustivat 34 eri kansallisuutta. Laaja edustavuus ei ole sinänsä tavoite, mutta koska seminaari nyt pantiin toimeen 20 . kerran, voidaan ilolla todeta, että koskaan aikaisemmin ei ole ollut mukana näin monia kansallisuuksia eri puolilta maailmaa.

\section{Miten he seminaariin hakeutuvat?}

Seminaarin yleisjärjestelyt rahoitetaan opetusministeriön myöntämällä määrärahalla. Siitä ilmoitetaan Adult Education in Finland lehdessä, ja verraten moni tätä vaatimatonta, mutta maailmalla yllättävän hyvin tunnettua lehteä anomuksista päätellen lukeekin.
Merkittävä osa kuitenkin saa järjestö- tai laitoskohtaisen kutsun joko European Bureau of Adult Educationin tai International Council for Adult Education kautta, joiden jäsen järjestäiä, VSY, on.

Eri puolilla maailmaa järjestetään samantapaisia tilaisuuksia, mutta eräässä suhteessa meidän Meetingimme poikkeaa edukseen useimmista. Siihen nimittäin osallistuu aina edustajia Itä-Euroopan maista sekä eri maanosien kehitysmaista. VSY onkin määrätietoisesti pyrkinyt kehittämään seminaarista idän ja lännen, etelän ja pohjoisen kohtauspaikan, ja tässä pyrkimyksessä ei vastaavalla tavalla ole mikään muu järjestäjä onnistunut. Käytäntö on osoittanut, että juuri mahdollisuus vuoropuheluun sosialististen ja kehitysmaiden edustajien kanssa vetää osanottajia Länsi-Euroopasta, USA:sta ja Kanadasta Meeting in Finland -seminaariin. Sosialistisista maista saadaan osanottajia mm. siksi, että heidän edustuksestaan on sovittu Suomen ja asianomaisen maan välisessä kulttuurivaihtosopimuksessa. Myös muiden maiden kanssa voimassa olevat vaihtosopimukset tuntevat yhä useammin Meetingin, niin että seminaarilla on tietynlaisena laatutakeena puolivirallinen leima.

Uhrattakoon vielä muutama sana rekrytoinnille. Monilla sivistysjärjestöillä on kehitysyhteistyöprojekteja. Niitä hyväksi käyttäen on voitu saada hyvä edustus kehitysmaista. Ja lopuksi: International Council for Adult Education kokoaa rauhankasvatusverkostonsa jäseniä Meetingiin sekä muutoinkin 'mainostaa' sitä tiedotteissaan sen tarjoaman ainutlaatuisen luonteen takia.

\section{Ohjelma ja työskentely}

Tämän vuoden vierailija-alustukset aloitti Englannin yhteisjärjestön puheenjohtaja Peter Clyne analysoimalla maansa kasvatusalan lainsäädännön uudistusta (Educational Reform Bill 1987). Esitys valaisi niitä näkemyksiä, joita kasvatuksen kentällä toimivilla Englannissa on konservatiivisen hallituk- sen harjoittamasta politiikasta. Monelle esitys tuntui käyvän varoittavasta esimerkistä eli, mitä ei pitäisi tehdä.

Osanottajat odottivat - tänä perestroikan aikana - suurella mielenkiinnolla neuvostoliittolaisen Znanie-seuran edustajan, puhemiehistön jäsenen G.B. Bobosadykovan luentoa Vapaa-aika ja aikuiskasvatus. Esitys oli erittäin mielenkiintoinen, ja vakuuttava osoitus uudesta avoimmuudesta saatiin sen jälkeen, kun neuvostovaltuuskunnan edustajat ryhtyivät keskustelussa antamaan jonkin verran toisistaan poikkeavia tulkintoja eri ilmiöille.

'Afrikkalaisten' päivänä kuultiin yleisalustus siitä, kuinka monimuotoista aikuiskasvatus laajalla mantereella voi olla. Sen piti Afrikan aikuiskasvatusjärjestöjen liiton presidentti, prof. Anthony Setsabi Lesothosta. ANC:n edustaja Wintshi Njobe puolestaan valotti aikuiskasvatuksen asemaa 'Vailla kotimaata' eli Etelä-Afrikasta maanpaossa olevien ihmisten taistelussa oman asiansa puolesta. Jawaharlar Nehrun yliopiston edustaja prof. S.Y. Shah paneutui seikkaperäisesti yhden maan, Intian, aikuiskasvatuksen ongelmiin. Mielenkiintoisella tavalla erilainen taas oli se yhden maan tilanteen läpileikkaus, jonka antoi Nigaraguan viidennen alueen opetusministeri Hernan Sotelo Matus. Hänen esityksessään liehuivat vapaus- ja vallankumoustaistelun liput. Ennakkoon muutamat koti- ja ulkomaiset kollegat kyselivät, kuinka järjestäjät ovat rohjenneet panna peräkkäin alustamaan - tai ylimalkaan kutsua samaan seminaariin - nigaragualaisen ja amerikkalaisen. Mutta tilanteesta selvittiin. Amerikan aikuiskasvatusjärjestön presidentti Carroll Londoner saattoi omassa esityksessään todeta $\mathrm{mm}$., että taistelut ovat valitettavasti yhteisiä ja että ne pitäisi saada loppumaan, eikä vain sotatantereella. Hän nimittäin alusti Yhdysvaltain lukutaidottomuudesta. Maassa on 30 miljoonaa (todellakin) lukutaidotonta, ja vuodessa heistä voidaan saada opetuksen piiriin noin 3 miljoonaa. 


\section{Ei vain kuunneltu luentoja}

Meeting in Finland -seminaari haluaa olla keskusteleva tilaisuus. Niin ollen kaikki iltapäivät ja varhaisillat käytettiin kahdeksassa ryhmässä keskusteluihin. Niiden tulokset on koottu yli 30 sivuiseksi raportiksi, joita samoin kuin alustuksiakin on saatavissa (englanninkielisenä) järjestäjältä pientä maksua vastaan.

Suurin osa osanottajista ei luonnollisesti ollut aikaisemmin käynyt Suomessa. Valoisina ja miellyttävän helteisinä kesäiltoina saatettiin kuitenkin tutustua Suomeen, sen aikuiskasvatuksen eri muotoihin ja muuhun kulttuuriin.
Seminaaria edeltävään ohjelmaan, itse tilaisuuteen ja sen jälkeisiin aktiviteetteihin pääkaupunkiseudulla vieraat vakuuttivat olevansa tyytyväisiä. Mene ja tiedä, mutta yksi asia on varma: kaikki mahdollinen, mitä vieraiden viihtymiseksi oli tehtävissä, myös tehtiin.

\section{Osallistuisitko Sinäkin?}

En liioittele pahasti todetessani, että Meeting in Finland -seminaari on miltei tunnetumpi ulkomailla kuin Suomessa. Eräs suomalaisten osallistumista haitannut seikka on seminaarikieli eli englanti. Huonosti on levinnyt tieto siitä, että yleisistuntojen alustukset ja keskustelut tulkitaan suomeksi. Ryhmätöissä taas vähempikin kielitaito riittää, ja kulttuuri- ja sosiaaliset ohjelmat ovat tilanteina vieläkin helpommin selvitettävissä.

Meeting in Finland -seminaari on monessakin suhteessa ainutlaatuinen: se kokoaa ihmisiä kaikkialta maailmasta, se on joka vuosi, se tuo suomalaisille pikkurahalla sellaisen aikuiskasvatuksen rautaisannoksen, että muualta hakien saisi maksaa samasta paketista itsensä kipeäksi. Ei kansainvälisyyttä tarvitse aina muualta hakea. 